\title{
THE EFFECT OF TABATA EXERCISE ON FAT PERCENTAGE
}

\author{
Heni Yuli Handayani' ${ }^{1}$ Khoirul Anwar², Septyaningrum ${ }^{3}$ \\ STKIP PGRI Bangkalan ${ }^{1,2,3}$ \\ heni@stkippgri-bkl.ac.id
}

\begin{abstract}
The application of online learning in PJOK lessons is thought to be a trigger for the limited physical activity carried out by students, thus causing a decrease in physical fitness. The accumulated impact of decreased physical fitness causes an increase in the percentage of fat so that it puts an excessive burden on the performance of the heart and skeletal muscles in their activities. A solution to overcome concerns about the impact of PJOK online learning is proposed through tabata training with the interval method. Tabata is a physical activity by utilizing several workout movement items using the body's internal load on the limits of active and resting motion. The research method used an experimental method with a randomized pretest posttest design with a control group. Total sample was 15 students in each group was obtained, so that the total sample required was 30 students. Tabata exercise protocol using 8 squats, planks, mountain climbers, push ups, lunges, jamping jacks, back ups, and high knees for 15 meetings. Measurement of fat percentage using a skinfold caliper Data analysis using paired t-test. The results show that there was a significant effect of Tabata training on fat percentage.
\end{abstract}

Keywords: Tabata exercise, fat tercentage

Accepted: $25^{\text {th }}$ of January 2022

Correspondence author: Heni Yuli Handayani, STKIP PGRI Bangkalan, Indonesia.

E-Mail: heni@stkippgri-bkl.ac.id

DOI http://dx.doi.org/10.31851/hon.v5i1.6876 do

\section{(c) (†) (?)}

Jurnal Halaman Olahraga Nusantara licensed under a Creative Commons Attribution-ShareAlike 4.0 International License

\section{INTRODUCTION}

The COVID-19 pandemic situation has changed the face-to-face learning model to online learning. This certainly presents its own challenges for practical subject teachers such as PJOK teachers. PJOK learning is essentially a learning process by utilizing physical activity to obtain changes in individual qualities in terms of physical, mental, and emotional aspects (Okilanda et al., 2021). In the direct learning process, PJOK learning is related to movement skills from game/sports models accompanied by habituation of healthy lifestyles. With the change in learning models in a pandemic situation, the learning process, especially in PJOK subjects, also undergoes adjustments (Pranawati, 2019). 
The disruption of PJOK learning due to the pandemic has an impact on students' physical fitness. Decreased physical fitness in students due to limited physical activity increases the risk of overweight and even obesity in adolescents. In addition to the risk of increasing weight, another risk that arises is an increase in the percentage of body fat. The impact that arises from increasing the percentage of fat with an overweight body condition can increase the risk of type 2 diabetes mellitus, dyslipidemia, non-alcoholic fatty liver disease, coronary heart disease (WHO, 2018; Rankin et al., 2016; Park et al., 2012), high blood pressure (Gadde et al., 2018) stroke, some types of cancer, gallstones and osteoarthritis (Bales and Buhr, 2008). These risks should be a serious concern even though the opportunities occur in the future. The application of online learning in PJOK lessons is thought to be a trigger for the limited physical activity carried out by students, thereby causing a decrease in physical fitness. The accumulated impact of decreased physical fitness causes excess body weight, causing a feeling of laziness to move. While the percentage of excess fat puts an excessive burden on the performance of the heart and skeletal muscles in their activities (Adyani, 2020). A solution to overcome concerns about the impact of PJOK online learning is proposed through tabata training with the interval method.

Tabata is a physical activity by utilizing several workout movement items using the body's internal load on the limits of active and resting motion. Herlan and Komarudin (2020) revealed that the tabata workout only requires a relatively short time, but the results provided are very significant. Adyani's research (2020) proves that tabata training provides a $6.14 \%$ reduction in fat percentage. Dwinta (2016) also proves the results of tabata training provide a $6.8 \%$ reduction in fat percentage. However, the effect of online tabata training on fat percentage is still unclear.

On the basis of the above background, it is necessary to examine the effect of tabata training on fat percentage. 
Tabata lately is quite popular among the public. One reason is because this exercise only takes a short time of 4 minutes, but has tremendous benefits for the health of the body. Tabata is one type of interval training that is included in high intensity interval training (HIIT) or high intensity interval training. Until now, there have been many studies that mention that Tabata is considered very effective in burning calories and fat in the body.

\section{METHOD}

The research method used an experimental method with a randomized pretest posttest design with a control group. The population in this study were students of SMA Wachid Hasyim 2 Sidoarjo. The population in this study were students of SMA Wachid Hasyim 2 Sidoarjo. Determination of the sample in this study using consecutive sampling technique, so that a sample of 15 students in each group was obtained, so that the total sample required was 30 students. Tabata exercise protocol using 8 squats, planks, mountain climbers, push ups, lunges, jamping jacks, back ups, and high knees for 15 meetings. Measurement of fat percentage using a skinfold caliper which was measured in the biceps, triceps, suprailliaca, and subscapular areas.

Data analysis using SPSS. Hypothesis analysis by testing the effect using paired t-test in each research group. Paired t-test is used if the distribution of the data distribution is in the normal and homogeneous category. Hypothesis testing is accepted if the $\mathrm{p}$ value is less than 0.05 .

\section{RESULT AND DISCUSSION}

Table 1. Normalitas and Homogenity Test

\begin{tabular}{lcccc}
\hline \multirow{2}{*}{ Variabel } & $\mathrm{n}$ & \multicolumn{2}{c}{$\mathrm{p}$-Shapiro wilk } & $\mathrm{p}$-Levene's test \\
\cline { 3 - 5 } & & Control & Tabata &, 046 \\
\hline Biceps pretest & 15 &, 024 &, $157^{*}$ &, 010 \\
\hline Biceps posttest & 15 &, 037 &, 04 &, 044 \\
\hline Triceps pretest & 15 &, $052^{*}$ &, $81^{*}$ &, 041 \\
\hline Triceps posttest & 15 &, 038 &, $618^{*}$ & \\
\hline
\end{tabular}




\begin{tabular}{lcccc} 
Subscapula pretest & 15 &, $126^{*}$ &, 008 &, $367^{*}$ \\
\hline Subscapula posttest & 15 &, $084^{*}$ &, 016 &, $442^{*}$ \\
\hline Suprailiaca pretest & 15 &, 013 &, $599^{*}$ &, $171^{*}$ \\
\hline Suprailiaca posttest & 15 &, 015 &, $569^{*}$ &, $210^{*}$ \\
\hline
\end{tabular}

Tabel 2. Paired t-test

\begin{tabular}{|c|c|c|c|c|c|}
\hline \multirow[b]{2}{*}{ Variabel } & \multirow[b]{2}{*}{$\mathrm{n}$} & \multicolumn{4}{|c|}{ Rerata \pm devisiasion } \\
\hline & & Kontrol & p-sig & $\begin{array}{c}\text { Eksperime } \\
\mathrm{n}\end{array}$ & p-sig \\
\hline Biceps pretest & 15 & $9,6 \pm 6,7$ & 101 & $8,3 \pm 4,45$ & ,001 \\
\hline Biceps posttest & 15 & $9,9 \pm 6,5$ & ז & $6,67 \pm 3,8$ & * \\
\hline Triceps pretest & 15 & $\begin{array}{c}11,87 \pm \\
8,9\end{array}$ & 633 & $\begin{array}{c}11,9 \pm \\
4,49\end{array}$ & ,001 \\
\hline Triceps posttest & 15 & $11,97 \pm 9$ & & $11,1 \pm 4,8$ & \\
\hline Subscapula pretest & 15 & $\begin{array}{c}14,2 \pm \\
9,12\end{array}$ & & $\begin{array}{c}12,4 \pm \\
6,65\end{array}$ & 001 \\
\hline Subscapula posttest & 15 & $\begin{array}{c}14,4 \pm \\
8,75\end{array}$ & & $11,4 \pm 6,6$ & $*$ \\
\hline Suprailiaca pretest & 15 & $23 \pm 10,8$ & & $22,1 \pm 7,5$ & 000 \\
\hline Suprailiaca posttest & 15 & $\begin{array}{c}23 \pm \\
10,65\end{array}$ & 0 & $18,9 \pm 7,7$ & * \\
\hline
\end{tabular}

Based on table 2, the tabata training intervention given to the experimental group showed results that had a significant effect on all tested variables $(p<0.05)$. This is reinforced by the results of the mean difference between the final and initial tests which have a wide difference and indicate an increase in physical fitness and a decrease in fat percentage. In the control group, there is no significant effect. 


\section{Discussion}

The percentage of proven fat includes the biceps, triceps, subscapular, and suprailiac areas. The tabata exercise program intervention provided was in the form of squats, planks, mountain climbers, push ups, lunges, jumping jacks, back ups, and high knees. Each of these movements utilizes the same muscle group as the area for measuring fat percentage, thus providing a significant reduction in fat content in that area (Okilanda et al., 2018). The principle of performing movements that utilize high-intensity intervals with repetitions and interspersed with rest accelerates the decrease in the percentage of fat in the area. Based on the results of this study, it was found that the intervention of the tabata exercise program had a significant effect on reducing the percentage of fat. This is in line with previous research by Adyani (2020) proving that tabata training provided a $6.14 \%$ reduction in fat percentage. Dwinta (2016) also proves the results of tabata training provide a $6.8 \%$ reduction in fat percentage. Furthermore, Domaradzki's research (2020) shows that tabata exercise provides body mass index and body fat in overweight adolescents (Arisman et al., 2021).

Tabata exercise can reduce body fat percentage better because the form of exercise is carried out with a short duration but has a high training capacity and has a fairly high training load (Adil Wijaya \& Imam Syafi'i, 2018). Tabata is also an exercise that requires oxygen at $70 \%$ of the maximum oxygen consumed 67 for 60 minutes and a form of exercise that has a moderate instrument. This exercise is carried out with a capacity of $170 \%$ of the oxygen capacity consumed by the body so that tabata training is better effective in reducing body fat percent due to the form of exercise and the capacity of the exercise performed. In addition, tabata training also focuses on exercise performance on all members of the body and provides loads and exercises on all parts of the muscle so that it is more effective for controlling body weight, because of its ability to increase fat oxidation and reduce waist circumference (Adyani, 2020). 


\section{OLATRAGA}

JURKALJUII KEOLIMRIGLAH

Jendral A. Yani Street Lorong Gotong Royong 9/10 Ulu Palembang South Sumatera

\section{Fitness Component}

This component is very important to know because it is a determining factor of a person's fitness results. (Alba et al., 2019) states that fitness and health are interconnected and also have basic components, such as:

"1) Strength as the ability of muscles in the body to carry weights or perform activities. 2) Endurance is used for the ability of individuals in running organs in the body, such as the lungs, heart, and other organs efficiently and effectively. 3) Muscle Strength for the ability to produce full strength quickly. 4) Speed is used to measure the ability of muscles in the shortest possible movement time. 5) Flexibility as the ability to move the body flexibly. 6) Agility is a fast and varied ability in the muscles of the body in performing movements, such as movements moving from right to left, from front to back. 7) Coordination as the body's ability to connect various kinds of fast movements effectively. 8) Balance as the body's ability to monitor the body's organ systems and nerves so that it can control the body properly. 9) Accuracy is the body's ability as a motion controller in aiming at the target precisely. 10) Reaction as a stimulus to an object."

To support fitness can be given tabata exercise. "fittingness factor, lottery a bow without an arrow, lower-body burden breeding (low body-oriented circumference training), and upper-body burden breeding (shoulder, armrest and back-oriented circumference) were significant therein club"(Kim et al., 2015).

"Tabata is a method that involves comparing exercise with rest time during its implementation (using higt intensity intervals). The exercise of this method for four minutes details ( 20 seconds of exercise and 10 seconds of rest time) is given. This exercise uses a pattern of increased power in changing direction quickly" (Putra et al., 2020). Furthermore, "Tabata is a type of HIIT exercise that is popular around the world and has been developed. This tabata has a heavy load plus higt intensity on each participant's post that practices.ini able to increase defense if done continuously" Tabata exercises are exercises that can increase the change of physical components for the better (Arisman \& Noviarini, 2021) 


\section{CONCLUSION}

The tabata exercise program intervention provided was in the form of squats, planks, mountain climbers, push ups, lunges, jumping jacks, back ups, and high knees was a significant on fat percentage.

Tabata is also an improvised version of High Intensity Interval Training (HIIT) to improve fitness and performance, which typically combines a variety of cardio exercises, strength training, and so on at a time.

Tabata exercise is one type of HIIT that is designed to increase the body's metabolism when burning fat. Even through its high intensity, tabata is able to burn more fat than regular aerobic exercise for 60 minutes. Tabata increases the work of the heart and lungs to their maximum capacity. When the heart and lung muscles are strong, then the blood vessels can flow more and faster blood so that it can flow more oxygen into the muscle cells. This allows the body to burn more fat during previous exercise. That's why, tabata exercise is the most effective choice for instant weight loss.

Although the benefits of tabata sports are quite tempting, this sport is not suitable for everyone. Tabata involves a type of high-intensity physical activity. That is, we must make the most of all abilities and powers as much as possible. That's why tabata is intended for people who do have qualified body fitness because they have become accustomed to exercising. So, for those who are not used to exercising, it is not recommended to do so. On the other hand, there is always a greater risk of injury when we do high intensity exercise. So, do the preparation approximately for 10 minutes before training. 


\section{REFERENCES}

Adil Wijaya, M., \& Imam Syafi'i, M. K. (2018). Pengaruh Latihan Tabata

Terhadap Peningkatan VO2 Max Pada Academy Abyasa U-16 Kab. Nganjuk. Jurnal Prestasi Olahraga, 1(1), 1-7.

Adyani, Zayyana. 2020. Pengaruh Tabata Circuit Training terhadap Penurunan Berat Badan dan Persentase Lemak Tubuh pada Members Perigon Fitnes Studio. Skripsi: UNY

Alba, H. F., Mulyana, \& Subarjah, H. (2019). Pengaruh model latihan weight training dan motivasi latihan terhadap body fat dan body mass index (BMI). Jurnal Ilmu Keolahragaan, 18(2), 112-119.

Arisman, A., \& Noviarini, T. (2021). Tabata Workout dalam Meningkatkan Kebugaran Atlet Panahan. Halaman Olahraga Nusantara (Jurnal Ilmu Keolahragaan), 4(1), 12-22.

Arisman, A., Okilanda, A., Dwiansyah Putra, D., \& El Cintami Lanos, M. (2021). Resistensi Yoga dalam Meningkatkan Konsentrasi Ketepatan Memanah. Jurnal Patriot, 3, 71-81. https://doi.org/10.24036/patriot.v

Bales, C.W. and Buhr, G. (2008). Is Obesity Bad for Older Persons? A Systematic Review of the Pros and Cons of Weight Reduction in Later Life. Journal of the American Medical Directors Association, 9(5): 302-312. https://doi.org/10.1016/j.jamda.2008.01.006.

Domaradzki, J., Ireneusz Cichy, Andrzej Rokita, and Marek P. 2020. Effects of Tabata Training During Physical Education Classes on Body Composition, Aerobic Capacity, and Anaerobic Performance of Under, Normal, and Overweight Adolescents. Environmental Research and Public Health. 17, 876; doi:10.3390/ijerph17030876.

Dwinta, Alan. 2016. Pengaruh Latihan Circuit Body Weight terhadap Penurunan Berat Badan dan Persentase Lemak tubuh. Skripsi: UNY

Gadde, K. M., Martin, C.K., Berthoud, H.R. and Heymsfield, S.B. (2018). Obesity: Pathophysiology and Management. Journal of the American 


$\begin{array}{lllll}\text { College } & \text { of } & \text { Cardiology, } & 71(1): & 69-84 .\end{array}$

https://doi.org/10.1016/j.jacc.2017.11.011.

Herlan and Komarudin. (2020). Pengaruh Metode Latihan High-Intensity Interval Training (Tabata) terhadap Peningkatan Vo2Max Pelari Jarak Jauh', Jurnal Kepelatihan Olahraga, 12(1), pp. 11-17. Available at: http://ejournal.upi.edu/index.php/JKO.

Kim, H. B., Kim, S. H., \& So, W. Y. (2015). The relative importance of performance factors in Korean archery. Journal of Strength and Conditioning Research. https://doi.org/10.1519/JSC.0000000000000687

Okilanda, A., Arisman, A., Lestari, H., Lanos, M. E. C., Fajar, M., Putri, S. A. R., \& Sugarwanto, S. (2018). Sosialisasi Petanque Sebagai Olahraga Masa Kini. Jurnal Bagimu Negeri, 2(1), 69-76. https://doi.org/10.26638/jbn.638.8651

Okilanda, A., Dlis, F., Humaid, H., Putra, D. D., Arisman, A., \& Muslimin, M. (2021). Defense Warm-Up Exercise Material for 13-Age Athlete Using Video Technology in Covid-19 Era. International Journal of Human Movement and Sports Sciences, 9(4), 629-634. https://doi.org/10.13189/saj.2021.090404

Putra, D. D., Okilanda, A., Arisman, A., Lanos, M. E. C., Putri, S. A. R., Fajar, M., Lestari, H., \& Wanto, S. (2020). Kupas Tuntas Penelitian Pengembangan Model Borg \& Gall. Wahana Dedikasi : Jurnal PkM Ilmu Kependidikan, 3(1), 46. https://doi.org/10.31851/dedikasi.v3i1.5340

Park MH, Falconer C, Viner RM, Kinra S. (2012). The impact of childhood obesity on morbidity and mortality in adulthood: a systematic review.Obes Rev, 13(11): 985-1000.

Pranawati, Nela. 2019. Pengembangan Permainan Sportshall Circuit Games Untuk Meningkatkan Gerak Dasar Lokomotor Dan Enjoyment Pada Siswi Sekolah Dasar. Tesis. Program Studi Pendidikan Olahraga, Program Pascasarjana Universitas Negeri Surabaya. 


\section{OLAHRAGA}

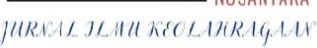

Jendral A. Yani Street Lorong Gotong Royong 9/10 Ulu

Rankin J, Matthews L, Cobley S, Han A, Sanders R, Wiltshire HD, et al. (2016).

Psychological consequences of childhood obesity: psychiatric comorbidity and prevention. Adolesc Health Med Ther, 7:125-146.

World Health Organization (WHO). (2018). Childhood overweight and obesity. Available from: http://www.who.int/dietphysicalactivity/childhood/en/. 